The Catholic University of America, Columbus School of Law

CUA Law Scholarship Repository

1970

\title{
Bartolomé de Las Casas and the Tradition of Medieval Law
}

\author{
Kenneth Pennington \\ The Catholic University of America, Columbus School of Law
}

Follow this and additional works at: https://scholarship.law.edu/scholar

Part of the Religion Law Commons

\section{Recommended Citation}

Kenneth Pennington, Bartolomé de Las Casas and the Tradition of Medieval Law, 39 CHURCH HIST. 149 (1970).

This Article is brought to you for free and open access by the Faculty Scholarship at CUA Law Scholarship Repository. It has been accepted for inclusion in Scholarly Articles and Other Contributions by an authorized administrator of CUA Law Scholarship Repository. For more information, please contact edinger@law.edu. 


\title{
Bartolome de Las Casas and the Tradition of Medieval Law
}

\author{
Kenneth J. Pennington, JR.
}

As a defender of the Indians and an opponent of the methods used by the Spanish conquistadors, Bartolomé de Las Casas was as controversial a figure in the sixteenth century as he has been in the last four hundred years of historiography. Las Casas' fight to preserve the freedom of the Indians has gained for him not only devoted admirers, but also angry detractors. ${ }^{1}$ Las Casas was not the only Spaniard who defended the Indians, but his efforts are the best known. He labored for fifty years before death finally halted the steady flow of polemics from his pen. However, he was not just a sheltered academician like Vitoria, but he actively championed the rights of the Indians by working and living among them in the New World.

In spite of Las Casas' prodigious literary output, comparatively little is known about his life. ${ }^{2}$ Nonetheless, most of his writings have been printed, giving modern scholars easy access to his thought. ${ }^{3}$ The scope of his work is rather broad, for he wrote not only polemical tracts but also some of the first histories about the New World. Not surprisingly, this vast welter of works has led scholars to construct a number of conflicting opinions as to why and how Las Casas came to the principles that he used to buttress his ideas on church and state,

1. The Lascasian literature is enormous. Lewis Hanke is the most eminent of the historians to have studied Las Casas; he and Manuel Giménz Fernández have compiled a bibliography of 849 entries. Bartolomé de Las Casas 1474-1566 (Santiago, Chili: José Toribio Medina, 1954). Hanke has described the controversy which surrounds Las Casas in a bibliographical note in his The Spanish Struggle for Justice in the Conquest of America (Philadelphia: University of Pennsylvania Press, 1949), 197199. The main argument centers around Las Casas' role in promoting the 'Black Legend," and whether Las Casas encouraged the Spanish slave trade through his writings.

2. Lewis Hanke, Las teorías políticas de Bartolmé de Las Casas (Buenos Aires: J. Peuser, 1935), 16, or his Bartolomé de Las Casas: Historian (Gainesville: University of Florida Press, 1952), 2. For a recent and sympathetic study with documentation see Henry Wagner, The Life and Writings of Bartolomé de Las Casas (Albuquerque: University of New Mexico Press, 1967). On this work see W. Borah's review in The American Historical Review, 73 (1968), 1268. Also the detailed work of Ramón Menéndez Pidal, El Padre Las Casas: Su doble personalidad (Madrid: Espana-Calpe, 1963), but see

$\rightarrow$ Silvio Zavala's review in Nueva Revista de Filología Hispánica, 17 (1963-1964), 104107. The most exhaustive work, which covers his life just up to 1523, is Manuel Giménez Fernández, Bartolomé de Las Casas, 2 volumes (Sevilla: Publicaciones de la escuela de estudios hispano-americanos de Sevilla, 1953-1960). Two recent articles are J. Specker, "Fray Bartolomé de Las Casas im Widerstreit der Meinungen," Neue Zeitschrift für Missionswissenschaft, 22 (1966), 213-233. Henri Bernard-Maitre, "A propos de la double personalité de Las Casas," Revue d'histoire ecclésiastique, 63 (1968), 63-66.

3. His historical works have been printed for centuries, and they are all in modern editions. Two of his most important polemical tracts have been edited only recently, Del unvco modo de atraer a todos los pueblos a la verdadera religion, edited by Augustin Millares Carlos (Panuco, Mexico: Fondo de cultura económica, 1942), and De thesauris in Peru, edited by Angel Losada (Madrid: Gonzalo F. de Oviedo, 1958).

Mr. Pennington is a graduate student of Medieval history in Cornell University. 
the prerogatives of the pope, and, most importantly, the rights of the inficlels vis-à-vis a Christian society.

There are two widely held views concerning the content and sources of Las Casas' views: the first is that his thought was largely Thomistic, and the second is that he was purely an activist who did not have a coherent position. The most common opinion is that Las Casas received his inspiration from St. Thomas Aquinas and his school of philosophy. P. Venancio D. Carro is representative of this group when he writes, "Las Casas' ideas are fundamentally the same as Vitoria's, Soto's and the other theologian-jurists cited from the sixteenth and seventeenth centuries, which is the natural flowering of the principles of St. Thomas, the Universal Doctor of the Church."4 The most extreme formulation of the second position is by an anonymous writer who doubted Las Casas' sanity. ${ }^{5}$ More common, however, is Silvio Zavala's statement, "like an advocate trying to impress the judge with the weight of all the arguments in favour of his case, Las Casas ... made use of various ideological expedients to protect the Indians from the consequences of the doctrine of natural servitude; particularly war, slavery and the encomiendas." Implicit in this statement is the thought that Las Casas used any argument at hand and that there was not any underlying coherence to his thought.

4. La theología y los teólogos-juristas españoles ante la conquista de América, 2 volumes (Madrid: Talleres gráficos Mariega, 1944), II, 314. "Las ideas de Las Casas son, en el fondo . . . las mismas Vitoria, Soto y demás teólogios-juristas citados del siglo XVI y XVII, que son floración natural de los principios de Santo Tomás, el Doctor universal de la Iglesia." He expands his views on Vitoria and Soto in the same work, I, 295. "Aun tropezamos con algunos supervivientes, inteligencias en retraso; pero la verdadera doctrina se impone ya pronto, con el renacimiento teológico-jurídico, que tendrá por capitanes a Vitoria y a Domingo de Soto. Este triunfo se debe, en primer lugar, al retorno a Santo Tomás en las Escuelas y Universidades." It has been conventional to view St. Thomas as being the dominant influence on these Spanish thinkers. Silvio Zavala has written in the introduction to Juan Lopez de Palacios Rubios, De las islas del mar Océano (Mexico: Fondo de cultura económica, 1954), lxix, "Sin embargo, la interpretación del poder pontificio como espiritual y ajeno a la potestad temporal directa, aunque con facultades de intervención en este dominio en lo que fuese necesario para el fin espiritual, se encuentra latente en los tratados de Tomás de Aquino, aflora con el español Torquemada en el siglo XV, y alcanza un desarrollo completo en Vitoria y Belarmino.' Bernice Hamilton, Political Thought in the Sixteenth Century (Oxford: Clarendon Press, 1963), also stresses the Thomistic influence on Vitoria, Soto and others. She even goes so far to say that the idea the pope could not grant dominion over the infidels was a view which was more common among theologians than lawyers (p. 179, footnote 1). Yves de la Brière, La conception du droit international chez les théologiens catholiques (Paris: 1930) has placed emphasis on the role of Thomism in Vitoria's and Soto's thought. The idea that Aristotle and Aquinas were chiefly responsible for creating theories which limited papal power is the thesis of Michael Wilks, The Problem of Sovereignty in the Later Middle Ages (Cambridge: Cambridge Unirersity Press, 1963).

5. "La locura de fray Bartolomé de Las Casas,', Revista hispanoamericana de ciencias, letras y artes, 6 (1927), 284-290. For the diverse attitudes towards Las Casas over four centuries, see Lewis Hanke, "Interpretación de la obra y significación de Bartholomé de Las Casas, desde el siglo XVI hasta el presente,'” Boltín latinoamérica, (1949), 295 300 .

6. The Political Philosophy of the Conquest of America, trans. by Teener Hall (Mexico: 1953), 70. Also Summerfield Baldwin, "God and Secular Power,' Essays in History and Political Theory Presented to Charles H. McIlwain (Cambridge, Mass.: Harvard University Press, 1936), 32. "Las Casas practically, Vitoria theoretically, both Dominicans, set themselves zealously to the defense of the Indians." 
Nevertheless, I should like to put forward a different point of view. Las Casas was not a pragmatic activist or a Thomist, but essentially a jurist whose ideas were based on medieval juridical theory. Just a glance at the analytical indices of Las Casas' printed works enables one to see how indebted he was to legal sources. In one of his last writings, De thesauris in Peru, Las Casas cited over twenty different canon and Roman lawyers, from Gratian to Panormitanus. In contrast, he referred to only four medieval theologians. ${ }^{7}$ Las Casas did not, moreover, use legal texts freakishly or hapazardly. To the contrary, he developed a central tradition of medieval legal thought in original and interesting ways.

Further, Las Casas was not unusual in this respect, but he was part of a general movement of adapting ecclesiological and canon law concepts to political theory. In this way, medieval legal thought helped to shape the fundamental political ideas of the sixteenth century. John Neville Figgis first explored how the theorists who created the doctrine of the divine right of kings based their arguments on canonical and ecclesiastical precedents, particularly the canonical notion of papal plenitudo potestatis. ${ }^{8}$ Since then, Ernst Kantorowicz, Brian Tierney, and Francis Oakley have done further work to clarify this process. Kantorowicz and Tierney have shown that medieval legal theory permeated many facets of the sixteenth century's political thought, ${ }^{9}$ while Oakley has pointed out that the conciliar writings of the late fourteenth and early fifteenth centuries, themselves based largely on the legal tradition, also had a significant influence on the writings of Jacques Almain, John Major, John Ponet, and Theodore Beza. ${ }^{10}$ So Las Casas' use of legal theory makes him an important figure in the mainstream of the development of early modern political thought.

The basic premise in Las Casas' position on the rights of the Indians is that legitimate secular power does exist outside the church. Las Casas insisted throughout his life that the Indians' dominium was legitimate and just, and that the Spaniards did not have the right to usurp the Indians' just title. From this basic principle sprung all the rest of Las Casas' ideas.

7. De thesauris, 465-469. Hanke has noted several times that Las Casas was learned in the law, but he did not emphasis the fact. See Lewis Hanke, Bartolomé de Las Casas: Bookman, Scholar, and Propagandist (Philadelphia: University of Pennsylvania Press, 1952), 15. Also Ernest Nys, "Les publicistes espagnols du XVIe siècle et les droits des Indiens," Revue de droit international et legislation comparée, 21 (1889), 532-560.

8. The Divine Right of Kings, 2nd. edition (Cambridge: Cambridge University Press, 1914), 45-65.

9. Ernst Kantorowicz, The King's Two Bodies: A Study in Mediaeval Political Theology (Princeton: Princeton University Press, 1957 $\rightarrow$ Brian Tierney, "Medieval Canon Law and Western Constitutionalism," Catholio Historical Review, 52 (1966-1967), 1-17.

10. Francis Oakley, The Political Thought of Pierre d'Ailly: The Voluntarist Tradition (New Haven and London: Yale University Press, 1964), 198-232. How thoroughly the writings of the conciliarists were based on canon law has been shown by Brian Tierney, Foundations of the Conciliar Theory: The Contribution of the Medieval Canonists from Gratian to the Great Schism (Cambridge: Cambridge University Press, 1955). 
Historical opinion has varied as to the novelty of Las Casas' claim that the dominium of the Indians was just. Figgis argued that it is a "thoroughgoing medievalism" to say that the dominium of infidels is unjust. ${ }^{11}$ If Figgis is right, then Las Casas' notions are original with the sixteenth century. Others, however, even before Figgis, had pointed out that there were two different strands of thought on this matter during the middle ages. The first held that the infidels' dominium was legitimate; the other denied that this was so. Both of these positions were first articulated by canonists. Pope Innocent IV maintained that the dominium of the infidel was just, while the canonist Alanus Anglicus, and after him, Hostiensis, asserted that there was not any legitimate secular power outside of the church. $^{12}$ Although no one has systematically studied later canonistic thought, it has been fashionable to state that the communis opinio of the later canonists followed the views of Alanus and Hostiensis. ${ }^{13}$ One reason for this is that historians have noted that the first writers to justify Spain's New World conquests, Matías de Paz and Juan Lopez de Palacios Rubios, used Hostiensis' argument that since the coming of Christ, all legitimate secular power was transferred to the Christian faithful. ${ }^{14}$ Historians have assumed that Hostiensis' opinion was the one that the canonists generally accepted. However, later canonists did not adopt Hostiensis' conclusions; rather they preferred the moderate doctrine of Innocent IV.

Certainly, a few canonists did adopt Hostiensis' formulation of

11. Studies of Political Thought from Gerson to Grotius 1414-1625 (Cambridge: Cambridge University Press, 1923), 18.

12. Nys, "Les publicistes,"' 552-553, noted that Innocent IV and Hostiensis took two different positions on this question in their commentaries on the Decretals of Gregory IX at $X$ 3.34.8 (Quod super his). Since then this has been discussed by Walter Ullmann, Medieval Papalism: The Political Theories of the Medieval Canonists (London: Methuen, 1949), 129-137. Zavala, De las islas, Ixxi-lxxxiii, discusses Innocent IV, Hostiensis, and Zabarella as well as other theologians and polemicists. See also his Political Philosophy, 25-27. Most recently, James Muldoon, "Extra ecclesiam non est imperium, The Canonists and the Iegitimacy of Secular Power,' Studia Gratiana, 9, 570-579. Alfons Stickler published a gloss of Alanus which denied that the infidels have legitimate power. Alanus may have been the first canonist (ca. 1202) to take this position. "Alanus Anglicus als Verteidger des monarchischen Papsttums," Salesianum, 21 (1959), 361-362. Gloss to D.96 c.6 s.v. cursu "Non obtitiat [obviat] huic opinioni quod ante fuerunt imperatores quam pape, quia tantum de facto fuerunt et ius gladii non habuerunt, nisi illi tantum qui in verum deum crediderunt. Nec etiam hodie habent infideles principes ut supra ostensum est ut xxiiii q.i. Set illud (c.39)."'

13. Zavala, De las islas, lxxxvii. "Veremos que en un principio prevalece la autoridad de Ostiense. Más tarde le escuela tomista afirma los derechos políticos y civiles de los pueblos gentiles, a pesar de su infidelidad." John Horace Parry, The spanish Theory of Empire in the Sixteenth Century (Cambridge: Cambridge University Press, 1940) 13-14. Muldoon, "Extra ecclesiam," 556; 578-580, also makes the point that the later canonists favored Hostiensis' opinion.

14. Henricus de Segusio, In quinque decretalium libri commentaria and In sextum decretalium librum, 2 volumes (Venetiis: 1581), II, fol. 128v. "Mihi tamen videtur, quod in adventu Christi omnis honor, et omnis principatus, et omne dominium, et iurisdictio de iure et ex causa iusta . . . omni infideli subtracta fuerit et ad fideles translata." Paz and Palacios Rubios used this text to promote Spanish claims. See Hanke, Spanish Struggle, 27-29. Parry, Spanish Theory, 13. De las islas for the text of Palacios Rubios' work. On Paz, see Vincente Beltrán de Heredia, "Un precursor del maestro Vitoria. El P. Matías de Paz, O.P., y su tratado De dominio Regum Hispaniae super Indos," La ciencia tomista, 40 (1929), 173-190. 
the problem. ${ }^{15}$ However, by the end of the fourteenth century, Innocent IV's commentary on Quod super had become the communis opinio of the canonists. The earliest canonist to sustain Innocent's position was Oldradus de Ponte. Oldradus wrote a consilium in the first decades of the fourteenth century in which he repeated Innocent's arguments for the just dominion of the infidels. Peculiarly though, Oldradus did not even mention that Hostiensis had put forward a powerful counter argument. ${ }^{16} \mathrm{~A}$ bit later, perhaps the greatest canonist of the fourteenth century, Johannes Andreae, reproduced the commentary of Hostiensis in his own work on the Decretals of Gregory IX. ${ }^{17}$ However, Johannes' stance on this issue is ambiguous. In his old age, when he wrote the Additiones to the Speculum iuris of Guilielmus Durantis, Johannes had changed over to the doctrine of Innocent IV. ${ }^{\mathbf{1 8}}$ Panormitanus and Francesco Zabarella, the most significant canonists of the next epoch, rejected Hostiensis and followed Innocent IV in their commentaries on X 3.34 .8 (Quod super his).$^{\mathbf{1 0}}$

15. Zenzelinus de Cassanis, Extravagantes Ioannis $X X I I$. . cum glossa (Antverpiae: 1572), Extrav. Jo. XXII 5.1 s.v. commisit. Cf. Ullmann, Medieval Papalism, 130-131. Later in the fourteenth century, Antonius de Butrio, Commentaria (Venetiis: 1578), III, fol. 151r, asserted that Hostiensis had tempered Innocent IV's opinion. "Et istam conclusionem Innocentii confirmat Hostiensis et temperat eam, ut infideles possent habere iurisdictionem in Christianos, quando infideles recognoscunt iurisdictionem ecclesie. Nam tales possunt habere, et possunt ex tolerantia ecclesie dominia, et iura habere: et si isti non sunt contenti illa iurisdictione, uel alias abuntur, sibi imputent: quia priuilegium meretur amittere."

16. Oldradus de Ponte, Consilia (Romae: 1472), consilium 264 (unfoliated). "Tertio eadem ratione, qua non debemus Iudaeos, et paganos, et Sarracenos pacificos rebus suis spoliare, eadem ratione nec eorum habitaculis et ex terra natiua priuare . . Et quod possident, iure gentis possident, siue res, siue loca, siue iurisdictiones et sic iuste, et iustitia fori, non poli ... sicut hoc clare tenet Innocentius ... Item causa expulsionis Amorraeorum, Cananaeorum, et Iebusareorum ab eorum terris per filios Israel est contra legem naturae, que clamat unum Deum ... Sed Iudaei et Sarraceni non sint idolatriae, sed alias infideles, neque tales publici hostes principum regentium Christianorum, ergo non debet expelli.",

17. Johannes Andreae, In quinque decretalium libros novella commentaria, 5 volumes in 4 (Venetiis: 1581; r.p. Torino: 1963), III, fol. 173r. For an introduction to the canonists who are mentioned here see the articles in the Dictionnaire de droit canonique, 7 volumes (Paris: Librairie Letouzey, 1957-1965). Gabriel Le Bras, Charles Lefebvre and J. Rambaud, Histoire du droit et des institutions de l'Eglise en Occident. L'Age classique 1440-1378: Sources et theorie du droit (Paris: Sirey, 1965). Johann F. von Schulte, Die Geschichte der Quellen und Literatur des canonischen Rechts von Gratian bis auf die Gegenwart, 3 volumes in 2 (Stuttgart: Ferdinand Enke, 1875-1878), is still useful. Also A. Van Hove, Prolegomena, 2nd. ed. (Romae: H. Dessain, 1945), has useful bibliographical information.

18. Johannes Andreae, Additiones to Guilielmus Durantis, Speculum iuris, 3 volumes (Venetiis: 1585), III, 488. Additio to De Iudaeis et Saracenis. "Vidi quaedam solennia scripta septem rationibus concludentia, quod princeps pacificos infideles de suis terris absque legitima causa non debet expellere ... Alias oves habeo, quae non sunt ex hoc ovili scilicet ecclesiae. . . Successor ergo Petri habet illas pascere et defendere, ergo non impugnare, vel laedi permittere. . . Item coelum coeli domino, terram autem dedit filiis hominum, ergo negandum eis non est, quod ius humanae societatis concedit."

19. Panormitanus (Nicolo Tedeschi), Commentaria, seu lecturae in quinque libros decretalium, 8 volumes (Lugduni: 1531-1555), VI, fol. 177v. "Innocentius multum exquisite tractat hic istam materiam et primo concludit quod infideles licite tenent dominia et principatus et alia bona quia deus subiecit orbem rationabili creature nec inter homines distinxit postea supervenit ius gentium et habuit locum illud." Francesco Zabarella, In librum primum(-quintum) decretalium, 5 volumes in 3 (Lugduni: 1557-1558), III, fol. 181r. "His premissis que sunt memoriter notanda quoad premissam questionem, dicit Innocentius quod dominia, possessiones et iurisdictiones licite sine peccato possunt esse apud infideles. Hec enim non tantum pro infidelibus sed pro qualibet rationibili creatura facta sunt. . ." From the beginning of the thirteenth century on, it was 
A consilium that the Bolognese lawyer, Dominicus de Sancto Geminiano, wrote at the beginning of the fifteenth century shows how thoroughly Innocent's doctrine became a part of the canonistic tradition. ${ }^{20}$ Dominicus concurred with Innocent's opinion that the dominum of the infidels was just ${ }^{21} \mathrm{He}$ commented further that the letter of Alexander II which seemed to give a basis for constant war against the infidel must not be interpreted universally, ${ }^{22}$ but that this decretal applied only to those lands which had been once subjected to the Roman Empire. ${ }^{23}$ Following Oldradus, Dominicus said that the Saracens were not idolators, and that if they lived in peace with Christians, they could not be expelled from their lands. ${ }^{24}$ At the end of the consilium, he gave a detailed refutation of Hostiensis' arguments because, as he said, no other canonist had yet done so. Dominicus concluded that the infidels' dominium is just and can not be taken away as long as they do not fight against Christians. ${ }^{25}$ As we shall soon see, Las Casas reached the same conclusions.

Although Paz and Palacios Rubios did hark back to the tradition of Hostiensis, ${ }^{26}$ the Spanish canonists of the late sixteenth cen-

quite common to declare that the imperial office could not exist outside of the church; this of course is not to say that there is not any legitimate secular power outside of Christendom. See Muldoon, "Extra ecclesiam.",

20. Dominicus de Sancto Geminiano, Consilia (Venetiis: 1581), consilium 96, fols. 80v-81v.

21. Ibid., fol. $80 \mathrm{v}$. "Ut notat Innocentius ... isti non potuissent occupare dicta loca, quia infideles, qui non expugnant fideles, non debent expelli de terris suis, cum licite possideant, cum de iure divino ante occupationem permissum fuit occupare terram cuilibet. .. Ex quibus concludit Innocentius quod non licet fidelibus nec etiam Papae sine causa iusta auferre infidelibus possessiones, dominia, vel iurisdictiones, quas tenent, cum iuste possideant."

22. This was the decretal that Gratian included in his Decretum at C.23 q.8 c.11. This chapter was used throughout the middle ages to justify the crusades.

23. Dominicus de Sancto Gemintano, op. cit., fol. 80v. "Verba ergo privilegii Alexandri ... quae dicunt, quod omnes terras, loca, ete. possint eripere de manibus paganorum, licet sint concepta universaliter, non debet intelligi sic universaliter, sed tantum de terris possessis per paganos, quae possent licite ab eis eripi, et non aliis, quae Papae non licet auferre de manibus illorum ... ita hic, dum dicit quod omnes terras possint eripere, intelligamus quod istud privilegium Alexandri non concedit indistincte eis omnia loca possessa per paganos, sed debet intelligi de locis, quae alias fuerunt subiecta Romano Imperio.'

24. Ibid., fol. 81v. "Sed Saraceni non sunt idolatrae, sed alias infideles, ergo expellendi non sunt, ex quo pacifice se habent cum Christianis haec sunt dicta oldradus in suo consilio 267 et Ioannes Andrea in additio Speculum super Rubrica de iudeis et saracensis. Ex quibus concluditur et roboratur opinio Innocentii in praelegato capitulo quod super his, quod princeps sine causa non potest expellere paganos de terris suis, quae non fuerunt sub dominio Christianorum ipsis pacifice viventibus." On Western European attitudes towards the Saracens, see M. W. Baldwin, "Western Attitudes towards Islam," Catholic Historical Review, 27 (1941-1942), 404-411. R. W. Southern, Western Views of Islam in the Middle Ages (Cambridge, Mass.: Harvard University Press, 1962).

25. Ibid. "Sed Hostiensis tenet contrarium in dicto capitulo, Quod super his, quia isti non respondent eius rationibus, est eis respondendum [this is probably a reference to Oldradus' failure to confront Hostiensis' arguments]. Propter quod concludit quod si infideles non recognoscunt ecclesiam Romanam in dominam [sic] nec illi obediunt, sunt indigni regno et principatu et omni iurisdictione." Dominicus then refuted each of Hostiensis' arguments. He concluded that ' hoc autem loquitur de infidelibus quiete manentibus et non impugnantibus Christianos.",

26. Although Hostiensis' opinion had been rejected by the canonists, his name was one of the most famous in the canonical tradition. This of course gave some weight to his opinion. Because Hostiensis undermined the very heart of Las Casas' argument, Las Casas attacked Hostiensis vigorously in Erudita et elegans explicatio quaestiones utrum Reges vel Principes iure aliquo vel titulo, salva conscientia, cives ac subditos a regea 
tury continued to agree with Innocent IV that the infidels' dominium was just. An example of this is the illustrious sixteenth century canonist, Didacus Covarruvias a Leyva. In a work which was dedicated to Phillip II, Didacus wrote a consilium entitled De bello adversus infideles. Here he concurred that the dominium of infidels was legitimate. ${ }^{27}$

So much for the canonists. It is clear that when Las Casas began his defense of the Indians, he could draw on this authoritative source for support. There were, however, theologians who declared that the infidels' dominium was legitimate, and it may be asked why Las Casas did not use this tradition. There seem to be two reasons for his choice. First, Las Casas used legal sources because they would carry more weight than the speculations of the theologians. Secondly, the theological tradition was more mixed than the canonistic tradition. Theologians did not reach a clear-cut decision on the justness of the dominium of infidels until the time of Vitoria. ${ }^{28}$ St. Thomas Aquinas, although he acknowledged the justness of the infidels' dominium, was closer to Hostiensis' position than to Innocent IV's when he said that the infidels could lose their dominium over Christians by reason of their infidelity. ${ }^{29}$ Innocent IV was much more moderate. He maintained that the pope could take away the dominium of an infidel prince who governed Christians only for a magna causa. Innocent thought that the pope could act if the prince seriously oppressed the Christians under him. ${ }^{\mathbf{3 0}}$ Theologians who wrote after St. Thomas took various

coronea alienare et alterius Domini particularis ditioni subjicere possint? (Francofurti: 1571), 13. "Qui error [Hostiensis] perniciosissimus est, et contra sacram Scripturam, et doctrinam omnium Sanctorum, et etiam piissimam Ecclesiae Consuetudinem, aditum praebens mille rapinis, bellis iniustis, homicidiis innumeris, et omni genere peccatorum, ut alibi contra eum, et suam sententiam esse haereticam." See Hanke, Las teorías politicas, 37.

27. Opera omnia, 2 volumes in 1 (Antverpiae: 1588), I, 497-499. "Sed nihilominus sit in hac re conclusio, quam veriorem esse censemus, bellum adversus infideles ex eo solum quod infideles sint, etiam auctoritate Imperatoris vel Papae iuste indici non potest . . nam infidelitas non privat infideles dominio, quod habent iure humano . . . ergo infideles ex eo quod infideles sunt, nee volunt Christi fidem suscipere, minime amittunt dominium rerum, nec provinciarum, quas obtinent, iureque humano habuerunt: quo sit, ut ex hac causa bellum adversus eos a Christianis etiam auctoritate publica indici iuste non valeat: quam conclusionem in specie veram esse censent Innocentius et Cardinalis [Francesco Zabarella] in dict. cap. Quod super his. ..." With this said, Muldoon's statement that "the canonists may have been too narrow in outlook to deal adequately with the complex issues of the Spanish conquest," seems a bit unfair. "A Canonistic Contribution to the Formation of International Law," The Jurist, 18 (1968), 265-279 at 278.

28. On the Spanish theologians of the sixteenth century see Hamilton, Political Thought, 61 ; 120-123. The wide audience that the theologians like Vitoria received has been primarily responsible for obscuring the fundamental contribution of the fourteenth and fifteenth century canonists.

29. Summa theologiae, 2.2.10.10. "Ideo distinctio fidelium et infidelium secundum se considerata non tollit dominium et praelationem infidelium supra fideles. Potest tamen iuste per sententiam vel ordinationem Ecclesiae, auctoritatem Dei habentis, tale ius dominii vel praelationis tolli; quia infideles merito suae infidelitatis merentur potestatem amittere super fideles, qui transferuntur in filios Dei."' St. Thomas' doctrine that an infidel prince would lose his power over Christians because that power was transfered to the sons of God is very similar to Hostiensis' theory.

30. Commentaria super libros quinque decretalium Gregorii IX, 2 volumes in 1 (Francofurti : 1570), fol. 430v. "Imo si male tractarent Christianos, potest eos privare per sententiam iurisdictione et dominio, quod super eos habnet, tamen magna causa debet 
stances. Aegidius Romanus, William of Cremona, and Wycliff had denied that the infidels' dominium was legitimate. In contrast, John of Paris, James of Viterbo, and Thomas of Strassburg agreed with the canonists. Interestingly, ideological considerations did not play a role in this discussion. Augustinus Triumphus, one of the most radical proponents of papal plenitude of power, was rather moderate on this issue. On the other hand, Hus' and Wycliff's doctrine that, if one did not have grace, one could not exercise legitimate dominium, effectively denied the legitimacy of the infidels' rule. ${ }^{31}$ It is not surprising then, that Las Casas used the canonistic commentaries while excluding the theological tradition. He did use theologians to supplement his argument, but he did not base his ideology on theology.

A particularly interesting exposition of Las Casas' ideas is found in a work of his last years, De thesauris in Peru. Las Casas wrote $D e$ thesauris in 1565 when he was ninety-one years old. In spite of his advanced age, he wrote a clear and vigorous defense of the Indians in this treatise. De thesauris contained the same canonistic arguments that Las Casas had used previously in his fight with royal bureaucrats and in his debate with Sepúlveda, which was his most renowned encounter. Sepúlveda had attempted to employ Aristotle to prove that the Indians were suited only for slavery and that Spain's claims to title in the New World were just. ${ }^{\mathbf{3 2}}$ To counter this argument, Las Casas did not quote the relevant texts from St. Thomas to establish that the Indians' dominium was legitimate. Instead, he supported his contentions with the standard canonistic citations. ${ }^{33}$

Although Las Casas relied entirely on canonical texts in this critical situation, he also used them extensively to sustain his other arguments. The method that he employed is rather interesting. Often he would cite a canonical legal maxim that he had taken from a particular case in canon law, and then he applied this maxim to the problem at hand. Las Casas did not, however, just repeat the arguments of the canonists, but he skillfully adapted them to a novel situation. The men of the sixteenth century were faced with an unfamiliar set of circumstances. New Lands had been opened to Europeans, and the European monarchs were claiming these lands as their own. The

esse, quod ad hoc veniat, debet enim Papa eos quantum potest sustinere, dummodo periculum non sit Christianis, nec grave scandalum generetur."

31. On the complexities of the theologians' thought on dominium, see Aubrey Gwynn, The English Austin Friars in the Time of Wycliff (London: Oxford University Press, 1940), 59-73, and Ewart Lewis, Medieval Political Ideas, 2 volumes (New York: Alfred A. Knopf, 1954), I, 103-104. On Augustinus Triumphus, especially see Wilks, Problem of Sovereignty, 419-420, where he also discusses Aegidius Spiritalis' views.

32. Juan Gines de Sepúlveda, Democrates segundo, ed. by Angel Losada (Madrid: Instituto Francisco Vitoria, 1951). Also Lewis Hanke, Aristotle and the American Indian (London: Hollis and Carter, 1959).

33. Las Casas, De thesauris, 88. "Per ea quae communiter omnes canonistae determinant in c. Quae in ecclesiarum, de constit. scilicet papam non posse privare infideles suis dominijs et iurisdictionibus quemadmodum nec christianos. Et signanter Innocentius in c. Quod super his, de voto. quam sententiam tenent etiam theologi studiosiores juris naturalis, et alibi latissime scripsimus." 
canonists had dealt with the legitimacy of rulers who were outside of Christendom during the middle ages, but they were then concerned with a hostile enemy, the Saracens. The situation in the New World was much different, for now the Christians were the exploiters and conquerors. This raised the moral question of whether it was just to conquer pacific non-Christians. Las Casas had to use the canonistic tradition in a situation that the canonists had never envisioned. His skill at doing this is evident in the section of his treatise where he attempted to prove that the pope could not give the temporal jurisdiction of the Indians to the Spanish kings.

Las Casas began this section of De thesauris by quoting the legal maxim which had originated in the private law of the Romans: Quod omnes tangit debet ab omnibus approbari; what touches all must be approved by all. Quod omnes tangit, from its humble beginnings in Roman private law, had become an important concept in the legal history of the middle ages. The canonists first used this principle to define the legal relationship between a bishop and his chapter of canons. Later, they introduced the maxim into ecclesiastical government where it supported the rights of the lesser members of the ecclesiastical hierarchy to have a hand in the governing of the church. And it became an important theoretical basis for the conciliar movement. Moreover, by the beginning of the fourteenth century, kings all over Europe were summoning representative assemblies of their noblemen, clergy, and townsmen. When they did, the reason that they often gave for calling such assemblies was, "what touches all must be approved by all."34 Thus Quod omnes tangit became part of the theoretical basis for parliament. In De thesauris, Las Casas used this maxim for yet another purpose. He observed that this principle had been developed to regulate the affairs of a bishopric; therefore, he went on, if one applied this principle properly, it would also be dangerous and undesirable if a prince or a bishop were given to an unwilling people. Nor, he added, should a king be given to a free foreign people. ${ }^{35}$ Consequently, Las Casas concluded, the pope can not give the infidels a new king without their consent. It follows then that the pope can not grant the Spanish king dominium in the New World without the consent of the

34. For a detailed history of this maxim's use during the middle ages, see Yves Congar, "Quod omnes tangit ab omnibus tractari et approbari debet," Revue historique de droit francaise et étranger, 35 (1958), 210-259, and Gaines Post, "A Romano-Canonical Maxim, Quod omnes tangit, in Bracton and in Early Parliaments," Studies in Medieval Legal Thought: Public Law and the State, 1100-1822 (Princeton: Princeton University Press, 1964), 163-238.

35. Las Casas, De thesauris, 202-204. "Ubi populus vocatur non ad eligendum tamen ad consentiendum electioni praelati per illam regulam iuris: Quod omnes tangit, debet ab omnibus approbari. cum suis concordantijs. lib. 6 et glossa in c.1 62 dist. Notant a contrario sensu quod si populus non vult consentire electioni factae per collegium, potest electio irritari .. Si ergo episcopus dari non debet invitis populis ne plebs invita episcopum contemnat vel odiat longe minus rector vel rex temporalis populo libero extraneo, gentili et infideli, proprios habenti et naturales reges non recognoscentes superiorem...." 
Indians. ${ }^{36}$ Las Casas used Quod omnes tangit in a manner which was reconcilable with the way that it had been used in the past, but he adroitly applied the maxim to a novel situation.

A striking aspect of this argument, aside from its canonical basis, is the premise that Las Casas used: that all the rules which are valid in the ecclesiastical polity ought to be valid in the secular polity. A1though not many political theorists would agree with that premise today, during the middle ages the church was a progressive body which was often ahead of the secular sphere in legal theorizing about its structure. As mentioned above, within the last few years ecclesiastical and legal historians have become aware of how many of the legal theories that the canonists had developed to regulate the church were applied to the secular state to help form the ideological framework for monarchial and constitutional government. ${ }^{37}$ Rather remarkably, Las Casas enounced this very idea in his treatise. One may argue, he said, from the practices in ecclesiastical institutions to what ought to be done in secular institutions. Further, he added, it is a good argument because St. Jerome used it. Therefore, because consent is required in ecclesiastical institutions, it ought to be necessary in secular institutions. ${ }^{38}$ In stating this, Las Casas described a phenomenon which had been taking place for three centuries in medieval Europe.

Las Casas also used ecclesiastical legal theory in other key instances. One of the most delicate problems that he faced was what Pope Alexander VI's bull of 1493 gave to the Spanish kings. Did this bull give the Spaniards the right to dominium in the New World, or did it just give them the right to propagate the faith ? $^{39}$ Las Casas thought that Alexander's donation only gave the Spaniards the privilege to propagate the faith; however, in De thesauris he indicated that the Spanish could gain a just title if they were able to obtain the consent of the Indians to Spanish rule. Las Casas used the same legal phraseology that the canonists had developed for episcopal elections.

36. Ibid., 206. “Ergo non potest [papa] eis dari rex novus nisi ipsi populi et quorum juri detrahitur voluntarie consenserint. Si ergo requiritur necessario quod gentes illae principesque illarum consentiant electioni vel institutioni de regibus nostris Hispaniarum factate per Papam in dominos universales orbis illius, cum negotium sit gravissinum et valde onerosum utopte contra regnorum illorum naturalem libertatem ac servilem deterioremque status omnium incolarum et regum seu magistratuum suorum conditionem, et propterea maxime odiosum: manifestum est oportere ad hoc eius modi consensum libere praestent."

37. Kantorowicz, King's Two Bodies, and Tierney, "Medieval Canon Law."

38. Las Casas, De thesauris, 202. "Potest addi alia confirmatio per argumentum ab institutionibus ecclesiasticis ad saeculares, quod est bonum argumentum quia eo utitur Hieronymus. I ad Corinthios, 10 et in multis alijs locis eo Ecclesia usa est. Sed in ecclesiasticis institutionibus requiritur consensus et approbatio populi. Ergo ita oportet esse in saecularibus."

39. For a discussion of the various interpretations which were given to Alexander's bull see Silvio Zavala, New Viewpoints on the Spanish Colonization of America (Philadelpha: University of Pennsylvania Press, 1943), 17-28. Manuel Giménez Fernández, Nuevas consideraciones sobre la historia, sentido y valor de las bulas alejande 1493 referentes a las Indias (Sevilla: Anuario de estudias americanos, 1944). Lewis Hanke, Bartolomé de Las Casas: An Interpretation of his Life and Writings (Hague: Martinus Nijhoff, 1951), 36-38. 
He contended that the papal grant gave the Spanish king ius ad rem and not ius in re. Just as a prelate did not have a complete title (only $a d \mathrm{rem}$ ) to his benefice or bishopric until the title was confirmed (to in re), the Spanish king had only a title ad rem to the Indies. He conceded that the Spaniards could obtain a title in re if the Indians consented to the Spanish claim of dominium. ${ }^{40}$

It was imperative, of course, that Alexander's donation not be construed as giving what its words indicated literally: cum omnibus illarum dominiis et jurisdictionibus; with all their dominions and jurisdictions. Las Casas read what the canonists had to say about papal rescripts, and he concluded that the pope could not have meant what he said. The pope could not, after all, grant letters which prejudiced a third party, and the privilege of one party could not usurp the right of another. Concessions and privileges are to be made without injury to another party. ${ }^{41} \mathrm{He}$ observed that it would be absurd if the pope had actually taken the Indians' dominum away; all he gave to the Spanish was the right to preach the faith. ${ }^{42}$

These examples could be multiplied, but those that I have given here show that in the most crucial segments of Las Casas' argument, he based his conclusions wholly on legal theory. Las Casas found a tradition in the writings of the medieval canonists which was ideally suited to his purpose; even more important is that through his knowledge of legal sources (which is amazingly broad when one remembers

40. Las Casas, De thesauris, 280-282. "Sic est de regibus nostris: habent nempe electionem sive institutionem papalem, et sic titulum et jus ad regna illa, quod regum nemo christianorum de mundo habet. Sed adhuc restat illis aliud potentius et principalius jus obtinendum, scilicet consensus populorum et regum suorum ut ratam habeant dictam papalem institutionem, recipiendo eos universales dominos et principes supremos, tradendo eis libere regnorum illorum possessionem: quatenus jus acquirant in re reges nostri id est plenam consequantur potestatem exercendi iurisdictionem supremam et quae sunt supremi principis et regiae ae imperiali auctoritate reservata, ut ex dictis manifeste apparet. Ergo quandiu populi et habitores praefati cum regibus suis libere non consenserint, et caetera. tantum habuerunt reges nostri titulum et jus ad regna illa, non autem in regnis illis (id est), nullum exercendi iurisdictionem ut gerendi se pro supremis principibus habent facultatem. . . Sic de catholicis regibus nostris, quia donec populi praefati et reges eorum consensum sine plica vi aut metu praestiterint, rite aut recte jus in regnis illis, id est exercitium regiae potestatis (nisi jus ad rem et solum titulum) non habebunt." For the development of the concept ius ad rem, see Robert Benson, The Bishop-Elect: $A$ Study in Medieval Ecclesiastical Office (Princeton: Princeton Úniversity Press, 1968), 142-143.

41. Ibid., 94-96. “"Et ratio secundum Baldum in d.c. Cum olim. Quia concessio ex qua sequitur aliquid absurdum dicitur concessio captiosa. ff. de transac. 1. Cum aquillia. et ff. de haeredi. insti. 1. Illa institutio et 1. Ille autem. Et ideo papa non concedit literas cum praejudicio alieno. Praeterea nihil fieri debet ad aemulationem. ff. de operi. publi. 1. Opus. et privilegium unius non debet usurpare jus alterius. ff. de vulga. susti. 1. Ex facto. Nec naturalem facultatem impedire. ff. de oper. liberto. 1. Libertas negotiatori. Haec Baldus. Item privilegia et concessione intelliguntur fieri sine alterius injuria. $1.2 \S \mathrm{Si}$ quis principe, et $\S$ Merito. ff. ne quid in loco publi. . . . Rursus, aliorum honores non debent alijs nocere."

42. Ibid., 100. "Fatendum est omnino Summum Christi Vicarium in praedictis apostolicis literis et decreto praefatae institutionis, concessionis sive donationis ad reges nostros catholicos, per eandem institutionem, concessionem, etc., privare Reges et dominos naturales illius orbis suis regalibus dignitatibus, dominiis et jurisdictionibus. . . Deus et eius Vicarius intendunt, scilicet praedicationi Evangelii et fidei dilatationi et cultus divini plantationi, et animarum conversioni et saluti conducant sive conveniant." 
that he was not a professional lawyer $){ }^{43}$ he was able to construct a defense of the Indians which was solidly grounded on the centuriesold authority of the law.

By constructing his arguments in legal terms, Las Casas was able to bring enormous pressure to bear on the Spanish government which led eventually to the famous clash with Sepúlveda. Even the Emperor Charles V realized that he was not "above the law," and that he had to justify his titles in the New World. Although Las Casas' place in the canonical tradition of the late middle ages has never been fully appreciated, Lewis Hanke has remarked that "this thorough knowledge of the law which Las Casas came to acquire must help to explain the fact that few of his contemporaries chose to meet him on the field of theory." ${ }^{44}$ This is true, but it can be taken a step further. Certainly, in terms of the law, Las Casas' arguments-that the dominium of the Indians was just and that the Spanish kings could not take that dominum away without a just cause-were unimpeachable. Las Casas' opponents could not debate with him on these points because Las Casas had the results of three centuries of legal opinion on his side.

Las Casas' appeals to ecclesiastical law caused Charles V to reexamine Spain's claim to a just title in the Indies. It is obvious that in Catholic Spain, in the middle of the sixteenth century, the influence of the ecclesiastical law was not altogether minimal. One may not say that canon law had more than a moral coercive force in the secular sphere, but it is well to note that even those who wished to defend Spain's title, men like Paz and Palacios Rubios, used a canonist to support their polemics. On the other hand, Las Casas' later opponents, like Sepúlveda relied entirely on Aristotelian political philosophy. Doubtlessly, if Las Casas had used only philosophical speculation in his challenge, he would have gone unnoticed and perhaps unheard. It is a tribute to the vitality of the canonical tradition that Charles V had to take heed of a movement which was inimical to the aims of his government.

This also suggests a further thought. It has been noted that Spain was the only colonial power in which the question of the just titles arose. The other colonial powers at this time, the English and the Dutch, never had the same interest in the rights of the natives. The sources that Las Casas used suggest a reason for this. Stimulated by the crusades, the ecclesiastical law had had to develop theories which were preliminary to a nascent international law. As we have seen, the theories evolved at that time have a rather liberal, modern ring. Their concern for the autonomy and liberty of foreign peoples is still an issue today. The Roman lawyers and those who studied the

43. Although there is no evidence that he received a law degree, it is fairly certain that Las Casas studied law at the University of Salmanaca. Cf. Wagner, Las Casas, 4.

44. Hanke, Bartolomé de Las Casas: An Interpretation, 42. 
various national laws did not concern themselves with this issue. Thus when the reformation came to England and the Low Countries, the "popish" law was destroyed or at least rendered ineffectual. Consequently, even if there would have been someone, a Las Casas, in England or Holland, he would not have had an authoritative source with which to support his case. Although it is perhaps stretching a point, the plight of the American Indians today may, in some measure, be traced to the destruction of three centuries of legal philosophizing in the sixteenth century.

Therefore, one may agree at least in part with the statement that "under the fire and brimstone of his invective there existed a closely reasoned structure of political thought based upon the most fundamental concepts of medieval Europe."45 However, these concepts were not universal, but were part of the medieval legal tradition that the canonists had developed. Las Casas' novelty lies in how he applied these canonical theories to the multifarious, complex problems which the discovery of a new continent raised. It was not only with emotion and humanitarian ideals that Las Casas tried to alleviate the plight of the Indians, but also with the logic of the law.

45. Tbid., 36. 